There is evidence that these particles are atoms of mass about 3 , carrying two charges. Consequently the atom of nitrogen can be disintegrated in two wavs by collision with $\alpha$-particles : one by the escape of an $\mathrm{H}$ atom, and the other by the expulsion of mass 3 , and both processes occur independently. Atoms of mass 3 are also released from oxygen atoms, but $\mathrm{H}$ atoms cannot be detected.

It may be concluded, therefore, that atoms of mass 3 , carrying two positive charges, are components of the nuclei of nitrogen and oxygen.

This new atom is to be regarded as an isotope of helium, and should give nearly the same spectrum. The energy of motion of the atom of mass 3 expelled from nitrogen and oxygen is about 8 per cent. greater than the original energy of the $\alpha$-particle, showing that energy is liberated as a result of the disintegration. The atoms of mass 3 probably consist of three hydrogen nuclei with one binding electron, and atoms of helium of four hydrogen nuclei and two electrons. Apart from hydrogen itself, these atoms are important secondary units in the building up of atomic nuclei. In the light of the new experimental evidence, examples are given of the possible modes of formation of isotopes and possible structures of nitrogen and oxygen nuclei are considered. It is pointed out that close combinations may exist of $\mathrm{H}$ nuclei and electrons, giving rise to atoms of zero nuclear charge, and that such a conception is needed to explain the evolution of the heavy elements.

\section{The Rockefeller Gift to Medical Science.}

$\mathrm{A}^{\mathrm{S}}$ was announced in the Daily Mail of June $\mathrm{rr}$, A the Rockefeller Foundation for Medical Research has made the generous gift of a sum of $1,205,000 l$. for the advancement of teaching and research in the Medical School of University College and Hospital. Owing to the inconsiderate and premature manner in which the statement was made public, it is natural that some mistakes should have been made and the objects of the gift in certain respects misunderstood.

The reason for the delay in making a public announcement is that the Senate of the University of London has as yet had no opportunity of formally accepting the gift. When this had been done it was the intention to make it public through appropriate channels and in such a way that the people of England might appreciate the intention of the donors to give a manifest proof of the friendliness of their feelings towards the work that we are doing here and their appreciation of its value. We have reason to believe that they particularly wish this aspect to be emphasised. It should be remembered that the object of the Rockefeller Foundation is "the welfare of mankind," so that its benefits were not intended to be confined to the United States. The members of the Foundation desire it to be regarded as entrusted to them for this purpose, and the present endowment is not meant in any way as a charitable gift. In view of statements to the contrary, it is necessary to make it plain that no conditions are attached, and that the recipients are left free in a very wide sense to make the best use of the money for the benefit of medical science, and especially as to the details of its application. It will naturally be understood that the manner of its use has been the subject of much discussion between representatives of the Rockefeller Foundation and the institutions receiving the gift.

With regard to the objects to which it is proposed to devote the endowment, a few words on the history of the negotiations may be of interest. Towards the end of last year two representatives of the Rockefeller Foundation, Dr. Wickliffe Rose (General Director of NO. 2642 , VOL. IO5] the International Health Board) and Dr. Pearce (Adviser in Medical Education to the Foundation) arrived in London. Before proceeding further they called at University College. In the absence of Prof. Starling, they were received by the present writer, whom they gave to understand that they had come to make inquiries into the conditions of medical education in London. They were accordingly informed of the recent creation of medical and surgical "units," of their situations and the names of various gentlemen associated with these units from whom they might obtain further information. 'This they proceeded to do. Early in the present year they made another visit to University College with definite proposals, and were seen by Prof. Starling and Prof. Elliot Smith, who showed them what was necessary to be done for the adequate provision of instruction and research in the fundamental sciences of anatomy, physiology, and pharmacology. It was clear to them that the most pressing need was the building of a new anatomical institute, although the medical sciences themselves naturally required the larger proportion of any proposed gift.

In April four representatives of University College and Medical School visited the United States for the purpose of further conference. These were the Provost (Sir Gregory Foster), Dr. Blacker (Dean of the Medical School), Prof. T. R. Elliott (professor of medicine), and Prof, Elliot Smith (professor of anatomy). On their return they brought back the definite offer of this extremely generous gift, and speak with the greatest appreciation of the friendliness of the manner in which they were received, the spirit in which the offer was made, and in which it was impressed upon them that it should be accepted.

Owing to the premature publication of the scheme it was necessary to call a general college meeting on Friday last, at which the Provost made a statement of its actual terms. In the words of the Rockefeller Executive Committee, they are as follows: "(I) An institute of anatomy. (2) Increase of clinical facili. ties. (3) Clinical laboratories planned. (4) Increased maintenance costs. (5) Closely unified administration." The Medical School will receive 835,0ool. and the College $370,000 \mathrm{l}$. Further details of the ways in which it is proposed to utilise the money will be duly announced. At this meeting Prof. Elliot Smith pointed out that anatomy is to be understood as including in its purview the microscopic structure of the tissues, embryology, and a study of the factors govern. ing the development of form. It is further to be hoped that the working of the scheme will involve a much closer co-operation between the College and the medical departments, to the advantage of both.

It is perhaps advisable to direct attention to the fact that the gift is for the purpose of improving medical education and research. At the same time the hospital, as an institution for the cure of patients, will benefit indirectly, although doubtless its working expenses will be ingreased owing to the enlargement proposed.

W. M. BAYLISS.

\section{The Permanent Value of University Benefactions.}

$A \mathrm{~N}$ account of the opening of the new building of $\mathrm{A}$ the Department of Applied Statistics and Eugenics at University College, London, presented by Sir Herbert Bartlett, was given in last week's Nature. The speech made by Prof. Karl Pearson in seconding the vote of thanks to the donor contains certain truths which have a wider application that to the immediate audience, and we therefore reproduce it 
in the hope that it will help to force the present difficult situation of the universities upon the attention of the public.

Henry VI., 1422-61. You probably all think of him as a weakling, the monarch whose forces were cleared out of the best part of France by Joan of Arc-a man naturally almost imbecile, and dominated by his Queen and a succession of dukes, and finally deposed by the victorious House of York. I feel otherwise towards him. For forty-five years I have worked under his image in a niche of my library. On my rare visits to Cambridge I would raise my hat to his statue on the front lawn of the college he founded. He may have been a poor King, but I owe the six most useful years of my life to the freedom his benefaction gave me to travel and to study. Despised as a King, there are many of us who respect our Royal benefactor as a scholar and a gentleman.

The spirit in which the members of old Cambridge colleges regard their founders and benefactors is one that should take deeper root in our new universities.

It is not merely the recognition of the name, but the insight that shall appreciate what the benefactor desired us to achieve, and the determination of successive generations that the purpose of the benefaction shall be carried out.

There are only too many ways of disposing of money! In 1441 it might be done by wars in France, by endowing monasteries to expedite the passage of your soul through purgatory, but those who founded or extended great centres of learning have remained in men's affection for all time. Nowadays you can dispose of your money to party funds or to charities; your name will survive just as long as your money is unspent or you have more to give. But the man who gives generously to a great academic institute will, if he chooses ivisely, be certain of an ever-green memory.

In this institute we have had a number of benefactors, but three stand out for special mention on such an occasion as the present. The Worshipful Company of Drapers, who from 1903 onwards have assisted one section of our enterprise. Sir Francis Galton, who came of a family which has founded no fewer than three academic chairs, the Sedleian, the Savilian, and my own chair. Under his inspiration we work, and we are more than pleased to be better able to keep his memory fresh in our new buildings here than has been possible in the past in our cramped and temporary homes.

Lastly, we come to the benefactor whose benefaction is the subject of our gathering to-day. To him not only I, but every member of my staff feel daily gratitude for providing us with a more fitting, and, I will add, a more healthy environment, than we ever imagined would be ours, and I trust that the tradition will remain long after I have ceased to share the comfort of this building and the possibilities for the studious life it provides.

Those who have gone round this laboratory will have noted that we try to keep before us not only the portraits of great leaders of thought, but the portraits of the men who have made our work possible, and in this respect I should hope to be pardoned if I reminded Sir Ferbert Bartlett of how deeply we should all anpreciate the addition of such a memorial of his gift, so that we may have his form as well as his good works before us.

The war has left all academic enterprise stranded. In 1914 we could have equipped and fitted this build. ing from basement to ton story. Our contracts were rescinded, and for five years this laboratory was used as a military hospital. At present the fine buildings Sir Herbert Bartlett has provided lie to a large extent NO. 2642 , VOI. IO5] unoccupied. In 1871 the German nation made the extension of old and the founding of new universities a first claim on their war indemnities. In 1920 we hear no suggestion that from our universities a new national life has to spring, and that if they are to accomplish their task it can only be if the State and private friends come to their help in the present critical state of affairs. In this respect we can only trust that others will be as wise both for the present and for the future as Sir Herbert Bartlett has been. The winning of the war has been attributed in succession to many causes. One factor is rarely referred to, namely, the unselfish way in which the academic staff of university after university gave up their academic repose, broke through all their scholarly studies and their scientific researches, and, where they could not sacrifice their lives, at least sacrificed many of their best rears of work for national service. Voluntary, and unpaid, and unpayable gifts for national welfare! It is absurd that the universities should have to prate of such labours; but here is the fact, regard it in what aspect you like, that with a greater task than ever before them, they are left with far less power to carry it out than they had before the war, and it is that knowledge which makes us the more deeply grateful to the snecial benefactor whom we wish to honour in this vote of thanks. He saw our necessity and responded to it.

\section{The Imperial Entomological Conference.}

THE Committee of the Imperial Bureau of success of the Entomological Conference which the on June $I-I I$ in the Linnean Society's rooms, Burlington House, London. The conference was attended by twenty official delegates representing most of the British Dominions, Colonies, and Protectorates, as well as by members of the committee of the Bureau, while a number of entomologists were invited to the meetings and discussions which occupied most of the appointed days. At the opening of the conference the delegates were received by Viscount Harcourt, chairman of the rommittee, and business mestings were held on the first and final davs. On Fridar. June 4, the conference visited the Rothamsted Agricultural Experiment Station in conjunction with a meeting of the Association of Economic Biologists; an account of this interesting day appeared in last week's NATURE (p. 464). On Tuesday. June 8, the members journeved to Oxford, and on Thursday, June Io, to Cambridge. Prof. E. B. Poulton acted as host on the former, and Sir Arthur Shipley on the latter occasion. While the entomological collections in the University museums were the chief obiects of interest, time was found for brief inspection of some features of the historic cities; for example, after entertaining the conference to lunch in Christ's College. Sir Arthur Shipley took the Overseas delegates into the rooms occupjed ninety years ago by Charles Darwin.

Of the meetings held on the other five days of the conference it may bet said that several subjects of much importance and of general interest were well and earnestly discussed. On the morning of June 2 , under the presidency of Dr. R. Stewart MacDougall (Edinburgh), Mr. C. P. Lounsbury (Entomologist to the Union of South Africa) spoke on "I Iegislation in Regard to Plant Pests in the British Empire," insisting that the official entomologist should have authority to draft and enforce regulations against the introduction of plants which might harbour harmful insects; he advocated the drastic exclusion of such plants except in certain special cases, and expressed the opinion that little or no reliance can be placed on 